\title{
PITTING CORROSION TESTING OF STAINLESS STEEL AISI 304 IN CHLORIDE SOLUTIONS
}

\section{ISPITIVANJE PITING KOROZIJE NERdAJUĆEG ČELIKA AISI 304 U RASTVORIMA HLORIDA}

\author{
Originalni naučni rad / Original scientific paper \\ UDK / UDC: 620.193.4:669.14.018.841
}

Rad primljen / Paper received: Jul 2015

Key words: stainless steels, welded joint, pitting corrosion, pitting potential, critical pitting temperature

\author{
Adresa autora / Author's address: \\ *Institut za hemiju, tehnologiju i metalurgiju, IHTM, Centar za \\ elektrohemiju, Univerzitet u Beogradu, Beograd, Srbija
}

Institute of Chemistry, Technology and Metallurgy, IHTM, University of Belgrade, Belgrade, Serbia

Ključne reči: nerđajući čelici, zavareni spoj, piting korozija, piting potencijal, kritična temperatura pitinga

\section{Izvod}

Nerđajući čelici i njihovi zavareni spojevi često podležu piting koroziji u rastvorima koji sadrže hloridne jone. Ispitivanje piting korozije nerđajućih čelika se vrši primenom hemijskih i elektrohemijskih metoda. U ovom radu vršeno je ispitivanje piting korozije nerđajućeg čelika AISI 304 u rastvoru hlorida, bez prisustva i u prisustvu sulfatnih, odnosno nitratnih jona. Ispitivanja su izvedena u cilju određivanje efikasnosti navedenih jona u sprečavanju piting korozije, kao i prezentacije mogućnosti primenjenih metoda. Korišćene su elektrohemijske metode za određivanje piting potencijala $\left(E_{\text {pit }}\right)$ i određivanje kritične temperature pitinga ( $T_{\text {pit }}$. Vrednosti navedenih parametara predstavljaju merilo otpornosti nerđajućih čelika i njihovih zavarenih spojeva prema piting koroziji.

\section{UVOD}

Otpornost nerđajućih čelika i njihovih zavarenih spojeva prema koroziji je posledica formiranja tankog, adherentnog pasivnog filma na površini čelika, koji razdvaja čelik od korozione sredine. Stepen zaštite koju pruža pasivni film zavisi od njegove debljine, kontinuiteta, koherentnosti i adhezije za metal. Nerđajući čelici i njihovi zavareni spojevi su skloni nekim vidovima lokalne korozije kao što su piting, korozija u zazorima, interkristalna i naponska korozija. U prisustvu halogenih jona (npr. u vodenim rastvorima $\mathrm{NaCl}$ ), može doći do narušavanja kompaktnosti pasivnog filma $i$ obrazovanja pitova $[1,2]$. passive film and pit formation [1,2]. 
The destruction of the passive film in the presence of $\mathrm{NaCl}$ takes place locally, in places where the structure or thickness of the passive film is disturbed. In these places, the pit formation occurs [1]. In the case of welded joints pits are often formed in places with a specific microstructure.

Pits are easier to form in places of metallurgical heterogeneity. For example, pits are formed in chromium depleted areas in the austenitic stainless steels heated to a sensitization temperature. Pits can also be formed at the interface austenite-ferrite in welded joints of stainless steels.

The probability of pits formation in weld metal is large, because of the existence of microsegregations in the dendritic structure. Today, the welding consumables that have a higher resistance to pitting corrosion than the base metal are produced [3]. In stainless steels pits formation takes place almost exclusively in places of $\mathrm{MnS}$ inclusions. There is a certain correlation between the resistance to pitting corrosion and the size of MnS inclusions. With the reduction in the size of MnS inclusions (below $\sim 1 \mu \mathrm{m}$ ), significantly increases the resistance of stainless steels to pitting [4].

Therefore, the most important conditions for the formation of pits are: chemical composition and structural properties of welded joints of stainless steels, pitting potential and the presence of chloride ions in a test solution [1].

During formation of pits the electrochemical corrosion cell is formed between the passive metal surface and active metal (on the bottom of the pit). The presence of $\mathrm{Cl}^{-}$ions prevents the repassivation of the metal surface on the bottom of the pit, which is rapidly dissolved. During the hydrolysis of the metal ion at the bottom of the pit there is a decrease of $\mathrm{pH}$ value $(\mathrm{pH}=2$ to 3$)$, Figure 1. The potential difference between the passive metal surface, which acts as a cathode, and the bottom of the pit, which is active, is up to $200 \mathrm{mV}$ [5].
Razaranje pasivnog filma u prisustvu $\mathrm{NaCl}$ se odvija lokalno, na mestima gde je narušena struktura ili debljina pasivnog filma. Na tim mestima dolazi do obrazovanja pitova [1]. U slučaju zavarenih spojeva pitovi se često obrazuju na mestima sa određenom mikrostrukturom. Pitovi se lakše obrazuju na mestima metalurške heterogenosti metala. $\mathrm{Na}$ primer, hromom osiromašene oblasti, koje nastaju kada se austenitni nerđajući čelik zagreva do temperature na kojoj se odvija senzibilizacija, su podložne pitingu [3]. Pitovi takođe mogu da se obrazuju na granicama faza austenit-ferit u zavarenim spojevima nerđajućih čelika. Verovatnoća obrazovanja pitova u metalu šava je velika, zbog postojanja mikrosegregacija u dendritnoj strukturi. Danas se proizvode dodatni materijali za zavarivanje koji imaju veću otpornost prema piting koroziji nego osnovni metal [3]. Kod nerđajućih čelika obrazovanje pitova se odvija skoro isključivo na mestima MnS uključaka. Postoji određena korelacija između otpornosti prema piting koroziji i veličine MnS uključaka. Sa smanjenjem veličine MnS uključka (ispod $\sim 1 \mu \mathrm{m}$ ), znatno se povećava otpornost nerđajućeg čelika prema piting koroziji [4].

Prema tome, najvažniji uslovi za formiranje pitova su: sastav i strukturne osobine zavarenog spoja od nerđajućeg čelika, piting potencijal i prisustvo hloridnih jona u rastvoru [1].

Pri obrazovanju pita nastaje elektrohemijski korozioni spreg između pasivne površine metala i aktivne površine na dnu pita. Prisustvo $\mathrm{Cl}^{-}$jona onemogućava repasivaciju površine metala na dnu pita, koja se zato ubrzano anodno rastvara. Tokom hidrolize metalnih jona na dnu pita dolazi do smanjenja $\mathrm{pH}$ vrednosti $(\mathrm{pH}=2$ do 3 ), slika 1 . Razlika potencijala između pasivne površine, koja se ponaša katodno, i dna pita, koje se aktivno anodno rastvara iznosi do $200 \mathrm{mV}$ [5].

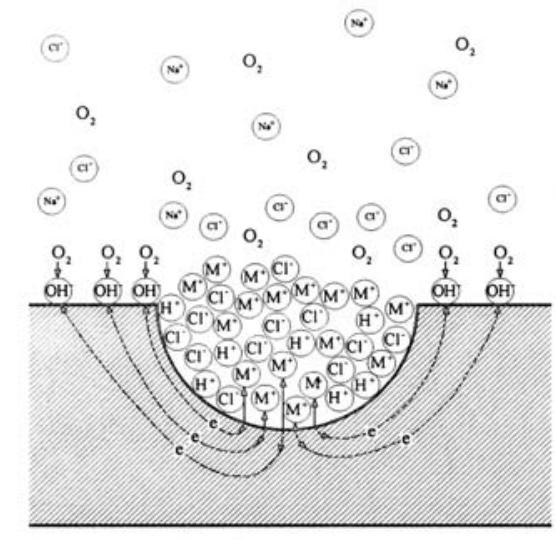

Figure 1. Formation and growth of pits [1]

Slika 1. Obrazovanje i rast pitova [1]. 
With increase in temperature the tendency of stainless steels and their welded joints to pits formation increases. Stable pits on stainless steels will not be formed if the temperature is below some critical value, called the critical pitting temperature, $\mathrm{T}_{\text {pit. }}$ The great influence of temperature on pitting corrosion led to the development of non electrochemical and electrochemical methods for the determination of the critical piting temperature. On the basis of the $T_{\text {pit }}$ value it is possible to rank stainless steels and their welded joints according to their resistance to pitting corrosion [6]. Unlike the pitting potential, which is determined as a potential range, $\mathrm{T}_{\text {pit }}$ value can be estimated more precisely (with a tolerance of 1 to $2^{\circ} \mathrm{C}$ ) [7].

ASTM standard G 48 prescribes the methods for determination of the pitting resistance of stainless steels in a solution of iron (III) chloride. The method A consists of the immersion of test samples in 6 wt. $\% \mathrm{FeCl}_{3}$ during a specified time. The method $\mathrm{C}$ is intended for the determination of the critical pitting temperature. It is carried out in an acidified solution of $\mathrm{FeCl}_{3}\left(6 \mathrm{wt}\right.$. $\% \mathrm{FeCl}_{3}+1$ wt. $\left.\% \mathrm{HCl}\right)$. The increase in temperature is performed in increments of $5{ }^{\circ} \mathrm{C}$, in the temperature range of $0{ }^{\circ} \mathrm{C}$ to $85^{\circ} \mathrm{C}$. The temperature at which pits are formed is considered to be the critical pitting temperature, $T_{\text {pit. }}$ These methods can be used to determine the influence of alloying elements, heat treatment and surface treatment, on the resistance of stainless steels to pitting corrosion.

The Nordic Innovation Centre has developed a method of testing the resistance to pitting corrosion for welded joints of stainless steels, based on ASTM standard G48 [8]. ASTM standard G 61 describes the procedure for performing electrochemical measurements, in order to determine the resistance of stainless steels to local forms of corrosion (pitting and crevice corrosion). In addition to pitting potential values $\left(E_{\text {pit }}\right)$, it is possible to determine the value of the protection potential ( $\left.E_{\text {prot }}\right)$ when the pits stop growing.

ASTM standard G 150 describes the procedure for assessing the resistance of stainless steels to pitting corrosion, which is based on electrochemical determination of $\mathrm{T}_{\text {pit. }}$. The increase in temperature is carried out gradually, from $0{ }^{\circ} \mathrm{C}$, at a rate of $1{ }^{\circ} \mathrm{C}$ $\min ^{-1}$, with simultaneous registration of the current density on the test sample. The sharp rise in electrical current at a certain temperature indicates that a stable pits growth has started. The temperature at which the current density reaches a value greater than $100 \mu \mathrm{A} \mathrm{cm}{ }^{-2}$ is considered to be the critical pitting temperature, $\mathrm{T}_{\text {pit }}$.
Sa povećanjem temperature raste sklonost nerđajućih čelika i njihovih zavarenih spojeva prema obrazovanju pitova. Do obrazovanja stabilnih pitova na nerđajućem čeliku neće doći ukoliko je temperatura niža od neke kritične vrednosti koja se naziva kritična temperatura pitinga, $\mathrm{T}_{\text {pit. }}$ Veliki uticaj temperature na piting koroziju doveo je do razvoja neelektrohemijskih i elektrohemijskih metoda za određivanje kritične temperature pri kojoj dolazi do obrazovanja pitova. $\mathrm{Na}$ osnovu vrednosti $\mathrm{T}_{\text {pit }}$ moguće je rangirati nerđajuće čelike i njihove zavarene spojeve u pogledu otpornosti prema piting koroziji [6]. Za razliku od piting potencijala $E_{\text {pit, koji se određuje }}$ kao oblast potencijala, $T_{\text {pit }}$ se može znatno preciznije odrediti (sa odstupanjem od 1 do $2{ }^{\circ} \mathrm{C}$ ) [7].

Standard ASTM G 48 obuhvata postupke za određivanje otpornosti prema pitingu nerđajućih čelika u rastvoru gvožđe (III) hlorida. Postupak $A$ se sastoji u potapanju uzoraka u $6 \% \mathrm{FeCl}_{3}$ u toku određenog vremena i koristi se za određivanje otpornosti prema piting koroziji. Postupak $\mathrm{C}$ je namenjen za određivanje kritične temperature pitinga. Izvodi se u zakiseljenom rastvoru $\mathrm{FeCl}_{3}$ (6 \% $\mathrm{FeCl}_{3}+1 \% \mathrm{HCl}$ ). Povećanje temperature vrši se $\mathrm{u}$ inkrementima od $5{ }^{\circ} \mathrm{C}$, u temperaturnom intervalu od $0{ }^{\circ} \mathrm{C}$ do $85^{\circ} \mathrm{C}$. Temperatura na kojoj dolazi do obrazovanja pitova smatra se kritičnom temperaturom pitinga $\mathrm{T}_{\text {pit. }}$. Navedeni postupci se mogu koristiti za određivanje uticaja legirajućih elemenata, termičke obrade, kao i površinske obrade, na otpornost nerđajućih čelika prema pitingu.

Nordijski inovacioni centar je razradio postupak za ispitivanje otpornosti prema pitingu zavarenih spojeva nerđajućih čelika, na osnovu standarda ASTM G 48 [8]. Standard ASTM G 61 opisuje postupak za izvođenje elektrohemijskih merenja, u cilju određivanja otpornosti nerđajućih čelika prema lokalnim vidovima korozije (piting i korozija u zazorima). Pored vrednosti piting potencijala ( $E_{\text {pit }}$ ), moguće je odrediti i vrednost zaštitnog potencijala (E $\left.E_{\text {prot}}\right)$, kada pitovi prestaju da rastu.

Standard ASTM G 150 opisuje postupak za procenu otpornosti nerđajućih čelika prema piting koroziji, koji je zasnovan na elektrohemijskom određivanju $\mathrm{T}_{\text {pit }}$. Povećanje temperature vrši se od $0{ }^{\circ} \mathrm{C}$, postepeno, brzinom od $1{ }^{\circ} \mathrm{C} \mathrm{min}^{-1}$, uz istovremeno registrovanje gustine struje na uzorku. Nagli porast struje pri određenoj temperaturi ukazuje da je došlo do stabilnog rasta pitova. Temperatura pri kojoj gustina struje dostigne vrednost veću od $100 \mu \mathrm{A} \mathrm{cm} \mathrm{cm}^{-2}$ smatra se kritičnom temperaturom pitinga, $\mathrm{T}_{\text {pit. }}$. 
Pitting corrosion can be prevented if the ions, which hinder the adsorption of $\mathrm{Cl}^{-}$ions or displace them from the surface of the stainless steel, are present in the solution. The addition of substances such as $\mathrm{NaNO}_{3}, \mathrm{Na}_{2} \mathrm{SO}_{4}$, etc. $[9,10]$ in a solution containing chloride ions shifts the pitting potential in the anodic direction and makes a stainless steel more resistant to pitting corrosion.

\section{EXPERIMENTAL}

The pitting resistance of AISI 304 stainless steel was tested by electrochemical determination of $E_{\text {pit }}$ and $T_{\text {pit }}[11,12]$.

Working electrodes made of AISI 304 stainless steel, in the shape of a disc, with a surface of 1.13 $\mathrm{cm}^{2}$ were prepared in the usual way: fine grinding, degreasing in ethanol and rinsing in distilled water. Tests were carried out in a solution of $0.2 \mathrm{M} \mathrm{NaCl}$, with and without the addition of sulfate or nitrate ions at a temperature of $25^{\circ} \mathrm{C}$. The working electrode was placed in an electrochemical cell with a reference electrode (saturated calomel electrode, SCE) and an auxiliary electrode (Pt foil).

After establishing a stable corrosion potential $\left(E_{\text {corr }}\right)$ anodic polarization curves were recorded until the current density reaches the value of $5000 \mu \mathrm{A} \mathrm{cm}$. The applied scan rate was $1 \mathrm{mV} \mathrm{s}^{-1}$. In some cases, after reaching the value of $5000 \mu \mathrm{A} \mathrm{cm}{ }^{-2}$, the polarisation curves were recorded in the backward direction, Figure 2. The potential value corresponding to the current density of $10 \mu \mathrm{A} \mathrm{cm}{ }^{-2}$ represents the $E_{\text {pit }}$ (on the polarization curve, recorded in the anodic direction), or the $E_{\text {prot }}$ (on the curve in the backward direction). At potentials more positive than the $E_{\text {pit }}$ the pits were formed which continue to growth stabily. In the potential range between $E_{\text {pit }}$ and $E_{\text {prot }}$ the formation of new pits did not occur, but the existing pits continue to grow. At potentials more negative than $E_{\text {prot }}$ the growth of formed pits is stopped.
Piting korozija se može sprečiti ukoliko su u rastvoru prisutni joni koji otežavaju adsorpciju $\mathrm{Cl}^{-}$ jona, ili ih istiskuju sa površine metala. Dodavanje supstanci koji sadrže ove jone (na primer $\mathrm{NaNO}_{3}$, $\mathrm{Na}_{2} \mathrm{SO}_{4}$ itd.) $[9,10]$ u rastvor koji sadrži hloride pomera piting potencijal $u$ anodnu oblast i čini nerđajući čelik otpornijim prema piting koroziji.

\section{EKSPERIMENTALNI DEO}

Ispitana je otpornost nerđajućeg čelika AISI 304 prema piting koroziji na osnovu elektrohemijskog određivanja piting potencijala $E_{\text {pit }} i$ kritične temperature pitinga $T_{\text {pit }}[11,12]$. Radne elektrode od nerđajućeg čelika AISI 304, izrađene u obliku diska površine $1,13 \mathrm{~cm}^{2}$, pripremljene su na uobičajen način: fino brušenje, odmašćivanje $u$ etanolu $i$ ispiranje u destilovanoj vodi.

Ispitivanja su vršena u rastvoru $0,2 \mathrm{M} \mathrm{NaCl}$, bez i sa dodatkom sulfata, odnosno nitrata, na temperaturi od $25{ }^{\circ} \mathrm{C}$. U elektrohemijsku ćeliju je postavljena referentna (zasićena kalomelova elektroda, ZKE) i pomoćna elektroda (Pt folija). Po uspostavljanju stabilnog korozionog potencijala $\left(E_{k o r}\right)$ snimljene su anodne krive polarizacije dok se ne dostigne gustina struje od $5000 \mu \mathrm{A} \mathrm{cm}^{-2}$. Brzina promene potencijala je bila $1 \mathrm{mV} \mathrm{s}^{-1}$. U nekim slučajevima, posle dostizanja struje od $5000 \mu \mathrm{A} \mathrm{cm}$ ${ }^{2}$, vršeno je registrovanje krivih polarizacije u povratnom smeru, slika 2.

Vrednost potencijala koja odgovara gustini struje od $10 \square \mathrm{A} \mathrm{cm}{ }^{-2}$ predstavlja $\mathrm{E}_{\text {pit }}$ (na krivoj polarizacije snimljenoj $u$ anodnom smeru), odnosno $E_{\text {prot }}$ (na krivoj u povratnom smeru). $\mathrm{Na}$ potencijalima pozitivnijim od $E_{\text {pit }}$ obrazuju se pitovi, koji dalje stabilno rastu. $U$ oblasti između $E_{\text {pit }}$ i $E_{\text {prot }}$ ne dolazi do obrazovanja novih pitova, već do rasta postojećih. Pri potencijalima negativnijim od $E_{\text {prot }}$ zaustavlja se rast obrazovanih pitova.

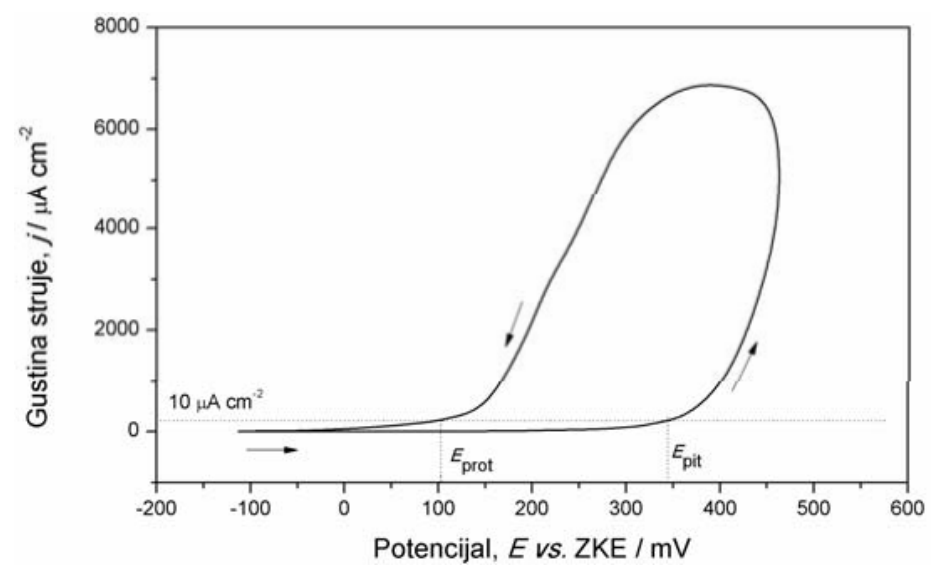

Figure 2. Determination of $E_{\text {pit }}$ and $E_{\text {prot }}$ for stainless steel AISI 304 in $0.2 \mathrm{M} \mathrm{NaCl}$.

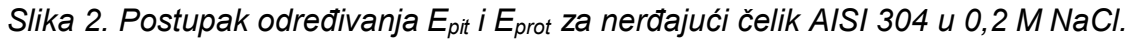


Potentiodynamic polarization curves for the examined stainless steel are shown in Figure 3. The curves were obtained in $0.2 \mathrm{M} \mathrm{NaCl}$, with no sulfate ions and in $0.2 \mathrm{M} \mathrm{NaCl}$ with different content of sulfate ions. It can be seen that the value of the $E_{\text {pit }}$ is the lowest in $0.2 \mathrm{M} \mathrm{NaCl}$ and grows in the presence of $\mathrm{SO}_{4}{ }^{2-}$ ions.
Na slici 3 prikazane su potenciodinamičke krive polarizacije za ispitivan nerđajući čelik, dobijene u $0,2 \mathrm{M} \mathrm{NaCl}$, bez sulfata i u $0,2 \mathrm{M} \mathrm{NaCl}$ sa različitim sadržajem sulfata. Sa slike se vidi da je vrednost $E_{\text {pit }}$ najniža u $0,2 \mathrm{M} \mathrm{NaCl}$ i da raste u prisustvu $\mathrm{SO}_{4}{ }^{2-}$ jona.

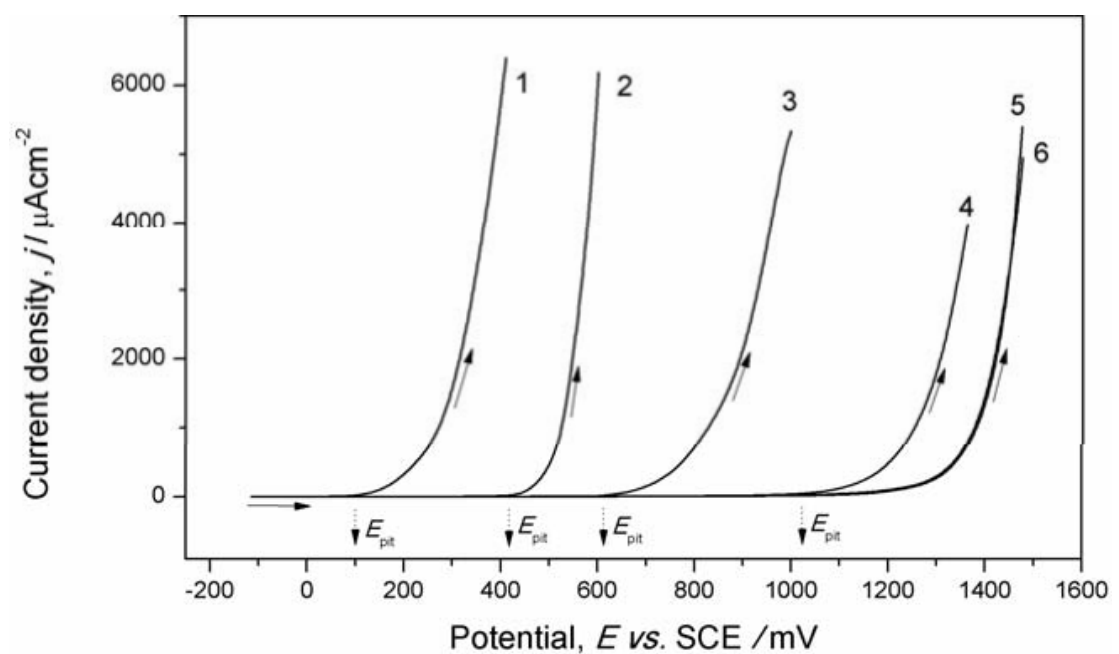

Figure 3. Anodic polarization curves for stainless steel AISI 304 in $0.2 \mathrm{M} \mathrm{NaCl}$ : (1) without sulfate ions, and with (2) $0.05 \mathrm{M}$ (3) $0.1 \mathrm{M}$ (4) $0.25 \mathrm{M}$ (5) $0.5 \mathrm{Mi}$ (6) $0.75 \mathrm{M} \mathrm{Na}_{2} \mathrm{SO}_{4}$, respectively.

Slika 3. Anodne krive polarizacije za nerđajući čelik AISI 304 u 0,2 M NaCl: (1) bez sulfata, i sa (2) 0,05M (3) 0,1M (4) 0,25M (5) $0,5 \mathrm{Mi}$ (6) $0,75 \mathrm{M} \mathrm{Na}_{2} \mathrm{SO}_{4}$, respektivno.

Potentiodynamic polarization curves of the examined stainless steel in $0.2 \mathrm{M} \mathrm{NaCl}$ with different content of nitrate ions are shown in Figure 4. It can be noticed that the pitting resistance of the tested steel is the lowest in a chloride solution $(0.2$ $\mathrm{M} \mathrm{NaCl}$ ) which does not contain nitrate ions. With the increase of nitrate ions content in the chloride solution the value of the $E_{\text {pit }}$ increases, i.e. the resistance to pitting corrosion increases.
$\mathrm{Na}$ slici 4 prikazane su potenciodinamičke krive polarizacije ispitivanog čelika u $0,2 \mathrm{M} \mathrm{NaCl}$ sa različitim sadržajem nitrata. Zapaža se da je otpornost ispitivanog čelika prema pitingu najmanja u rastvoru hlorida $(0,2 \mathrm{M} \mathrm{NaCl})$ koji ne sadrži nitrate. Sa povećanjem sadržaja nitrata u rastvoru hlorida povećava se vrednost $E_{\text {pit, }}$ odnosno otpornost prema piting koroziji.

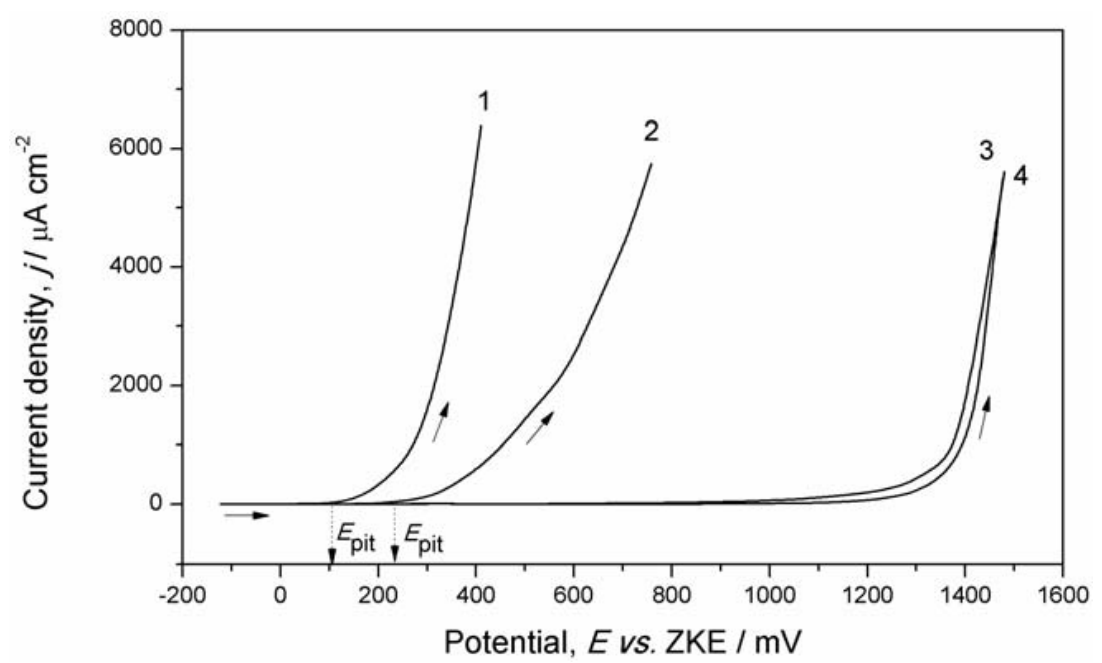

Figure 4. Anodic polarization curves for stainless steel AISI 304 in $0.2 \mathrm{M} \mathrm{NaCl:} \mathrm{(1)} \mathrm{without} \mathrm{nitrate} \mathrm{ions,} \mathrm{and} \mathrm{with} \mathrm{(2)}$ $0.01 \mathrm{M}$ (3) $0.02 \mathrm{M}$ (4) $0.1 \mathrm{M} \mathrm{NaNO}_{3}$, respectively.

Slika 4. Anodne krive polarizacije za nerđajući čelik AISI 304 u 0,2 M NaCl: (1) bez nitrata (2) 0,01M (3) 0,02M i (4) $0,1 \mathrm{MNaNO}_{3}$, respektivno. 
Testing of critical pitting temperature was performed in $0.2 \mathrm{M} \mathrm{NaCl}$, with and without the addition of nitrate or sulfate ions $[11,12]$. To maintain the necessary operating temperature during the test a thermostat was used. The electrochemical cell contains a working electrode (stainless steel 304), a reference electrode (SCE) and an auxiliary electrode (Pt foil). Simultaneously with the heating of the test solution, changes in the current of the test sample (working electrode) were recorded. The temperature at which the current density on the sample was greater than $100 \mu \mathrm{A} \mathrm{cm}$ 2 , was considered as the critical pitting temperature. The appropriate dependencies are shown in Figure 5.

The testing results of critical pitting temperature also show the less pitting resistance of the stainless steel AISI 304 in chloride solutions which do not contain nitrate or sulfate ions.
Ispitivanja kritične temperature pitinga su vršena u $0,2 \mathrm{M} \mathrm{NaCl}$, bez i sa dodatkom nitrata, odnosno sulfata [11,12]. Za održavanje potrebne radne temperature u toku ispitivanja korišćen je termostat. U elektrohemijsku ćeliju je postavljena radna elektroda (nerđajući čelik 304), referentna (ZKE) i pomoćna elektroda (Pt). Istovremeno sa zagrevanjem sistema vršeno je registrovanje promene struje na uzorku (radna elektroda). Temperatura pri kojoj je gustina struje na uzorku bila veća od $100 \mu \mathrm{A} \mathrm{cm}{ }^{-2}$, smatrana je kritičnom temperaturom pitinga. $\mathrm{Na}$ slici 5 prikazane su odgovarajuće zavisnosti dobijene u 0,2 M NaCl i u istom rastvoru u prisustvu sulfata, odnosno nitrata. Rezultati ispitivanja kritične temperature pitinga takođe pokazuju daleko manju otpornost nerđajućeg čelika AISI 304 prema piting koroziji u rastvoru hlorida koji ne sadrži nitrate, odnosno sulfate.

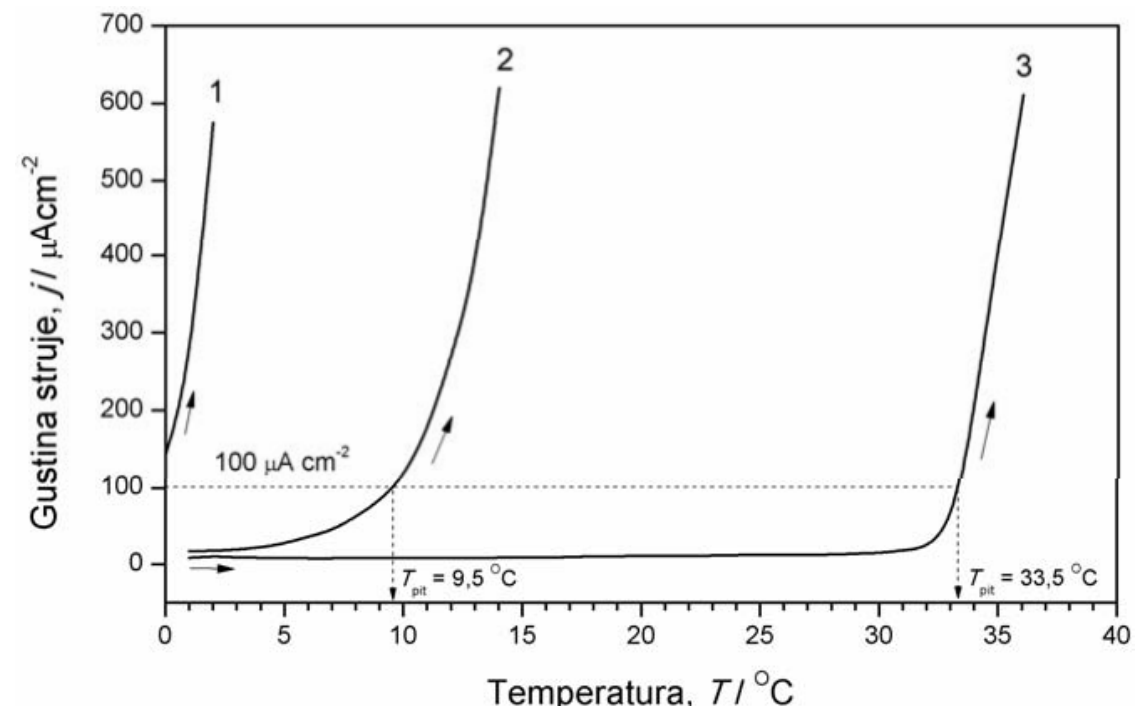

Figure 5. Determination of $T_{\text {pit }}$ for stainless steel AISI 304 in: (1) $0.2 \mathrm{M} \mathrm{NaCl}$ (2) $0.2 \mathrm{M} \mathrm{NaCl}+0.1 \mathrm{M} \mathrm{Na}_{2} \mathrm{SO}_{4}$ (3) $0.2 \mathrm{M} \mathrm{NaCl}+0.02 \mathrm{M}$ $\mathrm{NaNO}_{3}$

Slika 5. Kritična $T_{\text {pit }}$ za nerđajući čelik AISI 304 u rastvoru (1) $0,2 \mathrm{M} \mathrm{NaCl}$ (2) $0,2 \mathrm{M} \mathrm{NaCl}+0,1 \mathrm{M} \mathrm{Na}_{2} \mathrm{SO}_{4}$ (3) $0,2 \mathrm{M} \mathrm{NaCl}+0,02 \mathrm{M}$ $\mathrm{NaNO}_{3}$.

\section{DISCUSSION OF RESULTS}

Comparison of the results obtained (Figures 3 and 4) clearly shows that the resistance of AISI 304 stainless steel to pitting corrosion is the lowest in a solution of $0.2 \mathrm{M} \mathrm{NaCl}$. The resistance to this type of corrosion increases if the $\mathrm{SO}_{4}{ }^{2-}$ or $\mathrm{NO}_{3}{ }^{-}$ions are present in the chloride solution. These ions hinder the adsorption of $\mathrm{Cl}^{-}$ions, or displace them from the surface of the stainless steel. At a sufficiently high concentration of $\mathrm{NO}_{3}{ }^{-}$or $\mathrm{SO}_{4}{ }^{2-}$ ions in the chloride solution, the stainless steel AISI 304 becomes completely resistant to pitting corrosion (Figures 3 and 4). This is achieved when the ratio of the concentration of these ions and the concentration of $\mathrm{Cl}^{-}$ions is greater than 5 , in the case of

\section{ANALIZA I DISKUSIJA REZULTATA}

Upoređivanjem dobijenih rezultata (slike 3 i 4) jasno se uočava da je otpornost nerđajućeg čelika AISI 304 prema piting koroziji najmanja u rastvoru 0,2 M $\mathrm{NaCl}$. Otpornost prema ovom vidu korozije se povećava ukoliko su u rastvoru hlorida prisutni joni ( $\mathrm{SO}_{4}{ }^{2-}$ i $\mathrm{NO}_{3}{ }^{-}$joni), koji otežavaju adsorpciju $\mathrm{Cl}^{-}$ jona, ili in istiskuju sa površine metala. Pri dovoljno visokoj koncentraciji jona $\mathrm{NO}_{3}^{-}$ili $\mathrm{SO}_{4}{ }^{2-}$ u rastvoru hlorida, nerđajući čelik AISI 304 postaje potpuno otporan prema piting koroziji (slike 3 i 4). To se postiže kada je odnos koncentracija navedenih jona i koncentracije $\mathrm{Cl}^{-}$jona veći od 5 , u slučaju sulfata, odnosno veći od 0,1 u slučaju nitrata. To pokazuje da su $\mathrm{NO}_{3}{ }^{-}$joni znatno efikasniji i sprečavanju piting 
sulphates, or greater than 0,1 in the case of nitrates. This shows that $\mathrm{NO}_{3}{ }^{-}$ions are more efficient in preventing pitting corrosion of stainless steels in chloride solutions, which is in accordance with $[10,13]$. The values for the critical pitting temperature, $\mathrm{T}_{\text {pit }}$ (Figure 5) in chloride solutions, without the presence and in the presence of sulfate or nitrate ions, indicate less resistance of the tested stainless steel to pitting corrosion in chloride solutions which do not contain any nitrates or sulfates. The value of $T_{\text {pit }}$ in chloride solutions containing nitrates is considerably higher than the value of $\mathrm{T}_{\text {pit }}$ in solutions containing sulfates. This shows that $\mathrm{NO}_{3}^{-}$ions are significantly more effective inhibitors of pitting corrosion of stainless steels than $\mathrm{SO}_{4}{ }^{2-}$ ions.

The results of testing $T_{\text {pit }}$ indicate the adverse influence of increasing temperature on the formation of pits. For example the tested stainless steel AISI 304 is almost completely resistant to pitting corrosion in a solution of $0.2 \mathrm{M} \mathrm{NaCl}+0.02$ $\mathrm{M} \mathrm{NaNO}_{3}$ at $25{ }^{\circ} \mathrm{C}$. However, during testing of $\mathrm{T}_{\text {pit }}$ in the same solution, the formation of pits starts at the temperature of $\sim 33^{\circ} \mathrm{C}$.

\section{CONCLUSIONS}

Based on the results presented the following conclusions can be drawn:

The resistance of the stainless steel AISI 304 to pitting corrosion is the lowest in chloride solutions without sulphate or nitrate ions, as indicated by the lowest values of the $\mathrm{E}_{\text {pit }}$ and $\mathrm{T}_{\text {pit }}$.

The resistance to pitting corrosion increases with the addition of $\mathrm{NaNO}_{3}$ or $\mathrm{Na}_{2} \mathrm{SO}_{4}$ in chloride solutions.

$\mathrm{NO}_{3}{ }^{-}$ions are much more effective inhibitors of pitting corrosion than $\mathrm{SO}_{4}{ }^{2-}$ ions, considering that a significantly lower concentrations of $\mathrm{NO}_{3}{ }^{-}$ions is necessary to achieve a complete resistance of stainless steels to pitting corrosion.

The applied electrochemical methods for determining $E_{\text {pit }}$ and $T_{\text {pit }}$ enable studying the influence of different factors as temperature, chemical composition of the corrosive environment, etc. on the resistance of stainless steels and their welded joints to pitting corrosion.

\section{Acknowledgement}

This work was co-financed from the Ministry of Education, Science and Technological Development of the Republic of Serbia through projects TR 34028 and TR 34016. korozije nerđajućeg čelika u rastvorima hlorida, što je u skladu sa $[10,13]$.

Vrednosti za kritičnu $\mathrm{T}_{\text {pit }}$ (slika 5) u rastvoru hlorida, bez prisustva i u prisustvu sulfata, odnosno nitrata, ukazuju na daleko manju otpornost ispitivanog čelika prema pitingu u rastvoru hlorida koji ne sadrži nitrate, odnosno sulfate. Takođe, vrednost $\mathrm{T}_{\text {pit }} \mathrm{u}$ rastvoru hlorida koji sadrži nitrate je znatno veća nego vrednost $T_{p i t} u$ rastvoru koji sadrži sulfate. To pokazuje da su $\mathrm{NO}_{3}{ }^{-}$joni znatno efikasniji inhibitori piting korozije nerđajućih čelika nego $\mathrm{SO}_{4}{ }^{2-}$ joni.

Rezultati ispitivanja $T_{\text {pit }}$ ukazuju na nepovoljan uticaj povećanja temperature na obrazovanje pitova. Npr. ispitivani nerđajući čelik AISI 304 je praktično potpuno otporan prema piting koroziji $u$ rastvoru $0,2 \mathrm{M} \mathrm{NaCl}+0,02 \mathrm{M} \mathrm{NaNO}_{3}$, na $25{ }^{\circ} \mathrm{C}$. Međutim, tokom ispitivanja $T_{\text {pit, }} u$ istom rastvoru, na istom čeliku dolazi do obrazovanja pitova na temperaturi $\sim 33^{\circ} \mathrm{C}$.

\section{ZAKLJUČCI}

$\mathrm{Na}$ osnovu izvršenih ispitivanja piting korozije nerđajućeg čelika AISI 304 u rastvorima hlorida bez prisustva i u prisustvu sulfata, odnosno nitrata, može se zaključiti:

Otpornost prema piting koroziji je najmanja $u$ rastvoru hlorida koji ne sadrži sulfatne ili nitratne jone, na šta ukazuju najniže vrednosti $E_{\text {pit }} i T_{\text {pit. }}$

Otpornost prema piting koroziji se povećava sa dodatkom $\mathrm{NaNO}_{3}$, odnosno $\mathrm{Na}_{2} \mathrm{SO}_{4}$ u rastvor hlorida.

$\mathrm{NO}_{3}^{-}$joni su znatno efikasniji inhibitori piting korozije nerđajućeg čelika nego $\mathrm{SO}_{4}{ }^{2-}$ joni, $\mathrm{S}$ obzirom da je za postizanje potpune otpornosti prema piting koroziji potrebna znatno manja koncentracija $\mathrm{NO}_{3}{ }^{-}$jona.

Primenjene metode određivanja $E_{\text {pit }}$ i $T_{\text {pit }}$ omogućavaju ispitivanje uticaja različitih faktora (temperatura, sastav korozione sredine itd.) na otpornost nerđajućih čelika i njihovih zavarenih spojeva prema piting koroziji.

\section{Zahvalnica}

Rad je finansiran od strane Ministarstva za prosvetu, nauku i tehnološki razvoj Republike Srbije, kroz projekte TR 34028 i TR 34016. 


\section{LITERATURA}

1. G.S. Frankel, "Pitting Corrosion" in ASM Handbook, Volume 13A: Corrosion: Fundamentals, Testing, and Protection, Vol 13A, ASM Handbook, ASM International, 2003, p 236-241.

2. M. A. Streicher, "Austenitic and Ferritic Stainless Steels" in Uhlig's Corrosion Handbook, Second Edition, Ed. by R. W. Revie, 2000., p. $601-650$.

3. Corrosion of Stainless Steel Weldments, Corrosion: Fundamentals, Testing, and Protection, Vol 13A, ASM Handbook, ASM International, 2003, p 301-316

4. H. Bohni, "Localized Corrosion of Passive Metals", in Uhlig's Corrosion Handbook, Second Edition, Ed. by R. W. Revie, 2000., p. $173-190$.

5. D. Dražić and B. Jegdić, "Corrosion and Stress Corrosion Cracking", IFMASS8, Belgrade, 2003.

6. J. B. Lee, J. H. Shin, D. U. Shin and D. M. Lee, "Critical Pitting Temperatures for Stainless Steels Measured by Immersion, Potentiostatic and Potentiodynamic Polarization Methods", International Society of Electrochemistry - 55th Annual Meeting, Thessaloniki, 19 - 24 September, 2004.

7. M. H. Moayed, N. J. Laycock and R. C. Newman, "Dependence of the Critical Pitting Temperature on Surface Roughness", Corrosion Science, Vol. 45, 2003., p. 1203 - 1216.

8. TR 548: Improved Method for ASTM G 48 Corrosion Testing of Welds, Nordic Innovation Centre, Oslo, 2004.

9. L. L. Shrier, "Localized Corrosion" in in Corrosion, Ed. by L. L. Shreir, Oxford, 2000., p. 1:151 - 1:212.

10. I. L. Rozenfeld, "Inhibitory korrozii", Moskva, 1977.

11. B. Jegdić i B. Bobić, Piting korozija nerđajućih čelika. Deo II: Uticaj nitratnih jona na piting koroziju nerđajućih čelika u rastvoru hlorida, Zaštita materijala, Vol.46, Br. 3, Beograd, 2005., 25-30.

12. B. Bobić i B. Jegdić, Piting korozija nerđajućih čelika, Deo III: Uticaj sulfatnih jona na piting koroziju nerđajućih čelika u rastvorima hlorida, Zaštita materijala, Vol.47, Br. 2, Beograd, 2006., 17-22.

13. H. H. Uhlig and R.W.Revie, "Corrosion and Corrosion Control. An Introduction to Corrosion Science and Engineering", New York, 2008. 